\title{
Preferential mRNA Expression of Prostromelysin Relative to Procollagenase and In Situ Localization in Human Articular Cartilage
}

\author{
Quang Nguyen, ${ }^{\star 8}$ John S. Mort, ${ }^{\star 8}$ and Peter J. Roughley ${ }^{\star 8}$ \\ *Joint Diseases Laboratory and ${ }^{\ddagger}$ Genetics Unit, ${ }^{\S}$ Shriners Hospital for Crippled Children and Division of Surgical Research, \\ Department of Surgery, McGill University, Montreal, Quebec, Canada
}

\begin{abstract}
An imbalance between extracellular proteinases and their inhibitors is thought to underlie cartilage degradation. In cultures of adult cartilage, prostromelysin mRNA levels were much higher than those for procollagenase and this differential was increased in cultures stimulated with IL-1 $\beta$. Analysis of mRNA prepared from freshly isolated chondrocytes showed abundant amounts of prostromelysin mRNA in normal adult cartilage but low levels in the neonate. Not all adult cartilage may possess such high levels of prostromelysin mRNA, as the message levels in the cartilage remaining on late-stage osteoarthritic joints were lower than those in normal adult cartilage. Relative to prostromelysin mRNA, little procollagenase and TIMP mRNA were found in the adult cartilage. In situ hybridization revealed that metalloproteinase mRNAs were localized in chondrocytes of the superficial zone in adult cartilage. However, upon IL-1 $\beta$ treatment, chondrocytes in all cartilage zones were observed to express prostromelysin mRNA. Relative to the neonate, the normal adult cartilage appears to have a high degradative potential, if one accepts that steady-state mRNA levels reflect prostromelysin production. As the adult cartilage is not apparently undergoing rapid turnover, it would appear that control of prostromelysin activation may be the major regulatory step in stromelysin-induced cartilage degradation. ( $J$. Clin. Invest. 1992. 89:1189-1197.) Key words: aging • metalloproteinase $\bullet$ osteoarthritis $\bullet$ Northern blot $\bullet$ IL-1
\end{abstract}

\section{Introduction}

Connective tissue turnover during normal growth and development or under pathological conditions is thought to be mediated by a family of neutral metalloproteinases (1), which are zinc-containing enzymes that require calcium for full activity. These enzymes have been termed matrix metalloproteinases, and a classification system has been introduced whereby each enzyme has been designated a number based on the chronol-

Part of this study was presented at the 37th Annual Meeting of the Orthopaedic Research Society (1991) and was published in abstract form (Trans. Orthop. Res. Soc. [16: 196]).

Address reprint requests to Dr. J. S. Mort, Joint Diseases Laboratory, Shriners Hospital for Crippled Children, 1529 Cedar Avenue, Montreal, Quebec, Canada H3G 1 A6.

Received for publication 30 April 1991 and in revised form 22 November 1991.

J. Clin. Invest.

(c) The American Society for Clinical Investigation, Inc. 0021-9738/92/04/1189/09 \$2.00

Volume 89, April 1992, 1189-1197 ogy of its original discovery, collagenase being MMP- $1^{1}$ and stromelysin MMP-3 (2). A recent review reported the cDNA cloning of seven members of this family (3). Studies on collagenase and stromelysin have shown that these enzymes are secreted in a latent state and can be activated, in vitro, by the action of several proteinases (plasmin, kallikrein, mast cell tryptase, and trypsin) and other nonproteolytic agents, such as organomercurial compounds, sodium thiocyanate, oxidized glutathione and $N$-ethylmaleimide (4). It is thought that these activating agents perturb the interaction of a critical cysteine residue in the highly conserved propeptide domain of the metalloproteinases with the catalytic zinc atom, so that the active site becomes accessible to the substrates (4). However, it is still unclear whether a unique agent is responsible for metalloproteinase activation in vivo.

Collagenase specifically degrades collagen types I, II, III, VIII, and X $(1,5)$, while stromelysin has a wider substrate specificity, digesting cartilage proteoglycan, gelatin, collagen types IV, IX and XI, telopeptides of collagen types I and II, fibronectin, laminin, and elastin $(6,7)$. In addition, stromelysin can activate procollagenase, so further enhancing its destructive potential (8). The action of the activated metalloproteinases can be regulated through their interaction with proteinase inhibitors. A tissue inhibitor of metalloproteinases (TIMP) of $M_{\mathrm{r}} 28,000$ has been isolated from the culture medium of bone, cartilage, and synovial explants, and from body fluids $(9,10)$. The molecule is very stable to heat and acidic $\mathrm{pH}$, and it binds noncovalently to the metalloproteinases in a 1:1 molar complex to abolish their activities (9).

The detection of enhanced collagen and proteoglycan degrading activities in human osteoarthritic cartilage $(11,12)$, coupled with the abundance of procollagenase and prostromelysin detected at the invasive pannus and inflamed synovium in human rheumatoid joints $(13,14)$, have suggested the participation of these metalloproteinases in the destruction of arthritic cartilage. In the inflammatory arthritides, the degradation of cartilage is thought to be further accelerated by the action of various cytokines secreted by the neutrophils, monocytes and macrophages that infiltrate the proliferative synovium (15). Among the cytokines, IL-1 appears to be the most important mediator of inflammation and cartilage destruction. It has been shown that IL-1 stimulates the production of prostromelysin and procollagenase in connective tissue cells (16), and suppresses the synthesis of aggregating proteoglycan and cartilage-specific collagen types II and IX $(17,18)$.

In human cartilage explant cultures, it has been observed that prostromelysin is the major metalloproteinase secreted

1. Abbreviations used in this paper: CAP, collagenase activator protein; MMP, matrix metalloproteinase; PCR, polymerase chain reaction; TIMP, tissue inhibitor of metalloproteinases. 
into the culture medium, and that its production is strongly stimulated by IL- $1 \beta$, with little secretion of procollagenase being detected even in the presence of IL- $1 \beta$ (19). This is in contrast to the coordinated synthesis and stimulation of the metalloproteinases observed in monolayer cell culture systems derived from both cartilage and other connective tissues $(6,16)$. To further investigate this apparent discrepancy, we examined the synthetic potential of chondrocytes in human articular cartilage for metalloproteinase production.

\section{Methods}

Isolation of chondrocytes. Chondrocytes were isolated from normal femoral condylar cartilage obtained from neonates $(3,4$, and $5 \mathrm{mo})$ and adults $(50,79$, and $81 \mathrm{yr})$ within $20 \mathrm{~h}$ of death at autopsy, and from surgical samples of osteoarthritic cartilage of patients $(63,65$, and 74 yr) undergoing knee arthroplasty. Chondrocytes were also isolated from normal adult human cartilage ( $50 \mathrm{yr}$ ) explants cultured with or without IL- $1 \beta$ treatment as described below. Cartilage pieces were initially digested with trypsin $\left(5 \mathrm{mg} / \mathrm{g}\right.$ tissue) in DMEM at $37^{\circ} \mathrm{C}$ for $1 \mathrm{~h}$, followed by bacterial collagenase $(3,000 \mathrm{U} / \mathrm{g}$ tissue) and bovine testes hyaluronidase (4,500 U/g tissue) in DMEM-FCS for another 4-7 h. Tissue residue was removed by passing the digestion mixture through a $25-\mu \mathrm{m}$-pore size metal strainer. The cells were separated by centrifugation at $100 \mathrm{~g}$ for $5 \mathrm{~min}$.

Cartilage explant culture. Cartilage was diced into small pieces, and cultured, in the absence of serum, in Handley and Lowther's variation of DMEM at $1 \mathrm{ml} / 0.1 \mathrm{~g}$ wet weight of tissue (20). After an initial $2 \mathrm{~d}$, some cultures were supplemented with recombinant human IL-1 $\beta$ (Cistron Corp., Pine Brooke, NJ) at a concentration of $1 \mathrm{U} / \mathrm{ml}$ (19). This concentration of $I L-1 \beta$ has been shown previously to give maximal stimulation of prostromelysin production in this organ culture system (21). The cultures were maintained at $37^{\circ} \mathrm{C}$ for another $4 \mathrm{~d}$ with a change of medium every $2 \mathrm{~d}$.

Chondrocyte culture. Cells were isolated from normal adult femoral condylar cartilage (65 yr) as described above, then plated at $2 \times 10^{6}$ cells/ml in DMEM-FCS. After $2 \mathrm{~d}$, the medium was changed to serumfree DMEM for $1 \mathrm{~d}$, followed by culture in the presence or absence of $\mathrm{IL}-1 \beta(1 \mathrm{U} / \mathrm{ml})$ in DMEM for $48 \mathrm{~h}$.

Fibroblast culture. Normal human fetal skin fibroblasts (cell line GM0010; Human Genetic Mutant Cell Repository, Institute for Medical Research, Camden, NJ) were maintained and passaged in DMEM containing 10\% FCS (DMEM-FCS). Fibroblasts (sixth passage) were plated at a density of $10^{6} \mathrm{cells} / 75-\mathrm{cm}^{2}$ flask in DMEM-FCS. When the cells had reached near confluency, the medium was changed to serumfree DMEM. After $2 \mathrm{~d}$, some skin fibroblast cultures were treated with $\mathrm{IL}-1 \beta$ at $1 \mathrm{U} / \mathrm{ml}$ for $48 \mathrm{~h}$ at $37^{\circ} \mathrm{C}$.

Northern blotting analysis. Total cellular RNA was isolated from human chondrocytes and skin fibroblasts by the acid guanidinium thiocyanate/phenol chloroform extraction method (22). Total RNA (2.5 $\mu \mathrm{g} / \mathrm{lane}$ ) was fractionated on a $1 \%$ agarose gel containing $1.1 \% \mathrm{vol} / \mathrm{vol}$ formaldehyde and $0.25 \mu \mathrm{g} / \mathrm{ml}$ of ethidium bromide. After electrophoresis, the gel was rinsed in deionized water for $10 \mathrm{~min}$, and soaked sequentially in $50 \mathrm{mM} \mathrm{NaOH}, 0.5 \mathrm{M}$ Tris buffer, pH 7.0, and $10 \times \mathrm{SSC}$ $(1 \times \mathrm{SSC}=0.15 \mathrm{M} \mathrm{NaCl}, 0.015 \mathrm{M}$ sodium citrate) for $30 \mathrm{~min}$ each. The RNA was transferred onto GeneScreen hybridizing transfer membrane (New England Nuclear Research Products, Boston, MA) by capillary blotting overnight. The membrane was air-dried, then baked at $80^{\circ} \mathrm{C}$ for $2 \mathrm{~h}$.

The membrane was prehybridized at $42^{\circ} \mathrm{C}$ for $16 \mathrm{~h}$ in $5 \times \mathrm{SSC}, 50 \%$ formamide, $1 \times$ Denhardt's solution $(0.02 \%$ polyvinylpyrrolidone, $0.02 \%$ Ficoll, and $0.02 \% \mathrm{BSA}$ ), and $1 \%$ SDS, containing $100 \mu \mathrm{g} / \mathrm{ml}$ of denatured salmon sperm DNA (prehybridization buffer). Hybridization was carried out in the prehybridization buffer plus heat-denatured $\alpha-^{32} \mathrm{P}$-labeled probes, at $42^{\circ} \mathrm{C}$ for $16 \mathrm{~h}$. The membrane was washed in $2 \times$ SSC at room temperature for $5 \mathrm{~min}$, followed by $2 \times$ SSC containing
$1 \% \mathrm{SDS}$ at $65^{\circ} \mathrm{C}$ for $30 \mathrm{~min}$, and $0.1 \times \mathrm{SSC}$ at room temperature for another $30 \mathrm{~min}$. After drying, the membrane was exposed to Kodak $\mathrm{X}$-AR film at $-70^{\circ} \mathrm{C}$ with an intensifying screen. Equal loading of RNA samples was monitored by assessing the mRNA levels of human glyceraldehyde-3-phosphate-dehydrogenase (GAPDH), which is generally expressed at a similar level by all viable cells.

cDNA probes. cDNA clones for human procollagenase (MMP-1) (23) and human GAPDH (24) were obtained from American Type Culture Collection (Rockville, MD). A cDNA clone for human prostromelysin (MMP-3) (25) was kindly provided by Dr. C. Brinckerhoff (Dartmouth Medical School, Hanover, NH). The 1.3-kb BamHI fragment of the procollagenase insert, the 1.8-kb EcoRI fragment of the prostromelysin insert, and the 5.5-kb PstI linearized GAPDH plasmid were isolated after electrophoresis on a $0.8 \%$ agarose gel, using low melting agarose. The bands were cut and purified by the GeneClean procedure (Bio 101, La Jolla, CA). The cDNA probes were radiolabeled with $\left[\alpha{ }^{32} \mathrm{P}\right] \mathrm{dCTP}$ to a specific activity of $1.8 \times 10^{9} \mathrm{dpm} / \mu \mathrm{g}$, using a multiprime DNA labeling kit (Amersham International, Oakville, Ontario). When the 1.8-kb EcoRI fragment of the prostromelysin insert was used as a probe for Northern blotting analysis, it hybridized specifically to an mRNA transcript migrating just above the 18S rRNA marker $(1.86 \mathrm{~kb})$. An additional hybridized message, migrating just below the $28 \mathrm{~S}$ rRNA marker $(4.71 \mathrm{~kb})$, was also visible in the RNA sample of IL- $1 \beta$-stimulated cartilage cultures. The larger transcript presumably corresponds to the unprocessed prostromelysin mRNA precursor.

A cDNA fragment for human TIMP was prepared using the polymerase chain reaction (PCR). A first strand TIMP cDNA was prepared by reverse transcription of total RNA isolated from human skin fibroblasts (GM0010), after their culture in the presence of transforming growth factor- $\beta(2 \mathrm{ng} / \mathrm{ml})$ for $24 \mathrm{~h}$, using a 21 -oligonucleotide primer (5'-TATCTGGGACCGCAGGGACTG-3') complementary to a region between nucleotides 670 and 690 of the human TIMP cDNA sequence (26) and Moloney murine leukemia virus reverse transcriptase (Bethesda Research Laboratories, Gaithersburg, MD). The reaction was carried out at $42^{\circ} \mathrm{C}$ for $45 \mathrm{~min}$ in $20 \mu \mathrm{l}$ of $10 \mathrm{mM}$ Tris, $50 \mathrm{mM}$ $\mathrm{KCl}, 1.5 \mathrm{mM} \mathrm{MgCl}, 0.01 \%$ wt/vol gelatin, $\mathrm{pH} 8.3$ buffer (1× PCR) containing $2 \mu \mathrm{g}$ of total RNA, $1 \mathrm{mM}$ deoxynucleotide triphosphate mixture, $40 \mathrm{U}$ of human placental ribonuclease inhibitor (RNAsin; Promega Biotec, Madison, WI), 100 pmol of downstream oligonucleotide primer and $400 \mathrm{U}$ of reverse transcriptase. After denaturation at $95^{\circ} \mathrm{C}$ for $5 \mathrm{~min}$, followed by a 5 -min incubation at $4^{\circ} \mathrm{C}$, the reaction mixture was adjusted to a final volume of $100 \mu \mathrm{l}$ with $1 \times$ PCR buffer containing 2.5 units of Taq DNA polymerase (Perkin-Elmer/Cetus Corp., Norwalk, CT) and $100 \mathrm{pmol}$ of a 21-oligonucleotide primer (5'-TTCGTGGGGACACCAGAAGTC-3') coding for a region between nucleotides 208 and 228 of the human TIMP cDNA sequence. Second-strand TIMP cDNA synthesis and subsequent amplification reactions for the region ( $483 \mathrm{bp}$ ) defined by both upstream and downstream oligonucleotide primers were carried out on the DNA thermal cycler (Perkin-Elmer/Cetus Corp.). cDNA templates were denatured at $94^{\circ} \mathrm{C}$ for $45 \mathrm{~s}$, followed by a primer-annealing reaction at $60^{\circ} \mathrm{C}$ for 1 $\mathrm{min}$, and a primer extension reaction at $72^{\circ} \mathrm{C}$ for $2 \mathrm{~min}$. This series of reactions proceeded for 30 cycles. Amplified human TIMP cDNA was purified and labeled with $\left[\alpha-{ }^{32} \mathrm{P}\right] \mathrm{dCTP}$ by the same methods described for the other cDNA probes. The oligonucleotide primers were made using a DNA synthesizer (model 381 A; Applied Biosystems, Inc., Foster City, CA).

In situ hybridization. Normal cartilage samples obtained from an adult (79 yr) at autopsy and osteoarthritic cartilage obtained from patients (65 and $73 \mathrm{yr}$ ) undergoing knee arthroplasty, were fixed immediately in $10 \%$ formalin for $24 \mathrm{~h}$, then decalcified in $10 \%$ formalin containing $0.25 \mathrm{M}$ EDTA, $\mathrm{pH} 7.25$, at $4^{\circ} \mathrm{C}$ for $1-2 \mathrm{wk}$. Normal adult cartilage explants under IL- $1 \beta$ stimulation for $4 \mathrm{~d}$ were treated in the same manner. After fixation and decalcification, the samples were rinsed once with PBS, then equilibrated in PBS containing $0.5 \mathrm{M}$ sucrose at $4^{\circ} \mathrm{C}$ for $24 \mathrm{~h}$. The samples were snap frozen in OCT compound (Lab-Tek, Naperville, IL), and 6- $\mu \mathrm{m}$ sections were cut and placed onto 
microscope slides coated with poly-L-lysine. The conditions for prehybridization and hybridization were as follows. For prehybridization, the slides were immersed sequentially in the following solutions: PBS containing $0.3 \%$ Triton X-100 (15 min), twice in PBS (5 min each), 10 $\mathrm{mM}$ Tris/ $\mathrm{HCl}, 50 \mathrm{mM}$ EDTA, $\mathrm{pH} 8.0$ at $37^{\circ} \mathrm{C}$ (30 min), PBS containing $0.1 \mathrm{M}$ glycine ( $5 \mathrm{~min}$ ), post-fixed in $10 \%$ formalin ( $3 \mathrm{~min}$ ), washed in PBS ( $1 \mathrm{~min}$ ) and $0.1 \mathrm{M}$ triethanolamine, $0.25 \%$ acetic anhydride, $\mathrm{pH}$ $8.0(10 \mathrm{~min})$. The slides were rinsed with water and dried at $37^{\circ} \mathrm{C}$ for 10 min. The hybridization solution contained $50 \%$ formamide, $10 \%$ dextran sulfate, $1 \times$ Denhardt's solution, $0.6 \mathrm{M} \mathrm{NaCl}, 10 \mathrm{mM}$ Tris (pH 7.4), $0.5 \mathrm{mM}$ EDTA, $10 \mathrm{mM}$ DTT, $0.2 \mu \mathrm{g} / \mathrm{ml}$ tRNA and $\alpha-{ }^{35} \mathrm{~S}$-UTP-labeled riboprobes. A $50-\mu l$ aliquot of the hybridization solution $\left(3 \times 10^{6}\right.$ cpm) was applied to each slide, which was then covered with a siliconized coverslip, and incubated at $42^{\circ} \mathrm{C}$ for $24 \mathrm{~h}$. After hybridization, the sections were washed in the following solutions: $2 \times$ SSC- $10 \mathrm{mM}$ mercaptoethanol ( $30 \mathrm{~min}), 2 \times$ SSC-10 mM mercaptoethanol containing 1 $\mathrm{mg} / \mathrm{ml} \mathrm{RNase} A$ (30 min), $2 \times \mathrm{SSC}-10 \mathrm{mM}$ mercaptoethanol (30 min), and $0.1 \times$ SSC- $10 \mathrm{mM}$ mercaptoethanol at $65^{\circ} \mathrm{C}$ for $1 \mathrm{~h}$. After the sections were dehydrated in $70 \%$ ethanol- $0.3 \mathrm{M}$ ammonium acetate (5 $\mathrm{min}$ ) and $95 \%$ ethanol- $0.3 \mathrm{M}$ ammonium acetate $(5 \mathrm{~min})$, the slides were air-dried.

Autoradiography was performed by dipping the slides into Kodak NTB-2 nuclear track emulsion diluted $1: 1$ with $0.6 \mathrm{M}$ ammonium acetate, at $45^{\circ} \mathrm{C}$. After drying at room temperature for several hours, the slides were exposed in a desiccant-containing box at $-70^{\circ} \mathrm{C}$ for $\sim 2$ wk. The slides were developed in half-diluted Kodak D19 developer ( $2.5 \mathrm{~min}$ ), rinsed briefly in water, and fixed in a $24 \%$ sodium thiosulphate solution ( $5 \mathrm{~min})$. The sections were counterstained with Safranin O, dehydrated, and mounted with permount.

Riboprobes. The EcoRI prostromelysin insert in pUC19 was subcloned into pGEM-4 (Promega, Montreal, Quebec). The plasmid was then linearized with BamHI or BglI to generate the templates for the production of sense and antisense riboprobes, respectively. The BamHI and BglI-linearized plasmids ( $1 \mu \mathrm{g} /$ reaction) were transcribed in vitro using SP6 RNA polymerase and T7 RNA polymerase (Promega Biotec, Madison, WI), respectively, at $20 \mathrm{U} /$ reaction in a $20 \mu \mathrm{l}$ reaction volume containing $0.5 \mathrm{mmol}$ each of ATP, GTP, CTP, $12 \mu \mathrm{mol}$ of $\mathrm{UTP}$, and $300 \mu \mathrm{Ci}$ of $\left[\alpha^{-35} \mathrm{~S}\right] \mathrm{UTP}$, at $37^{\circ} \mathrm{C}$ for $1 \mathrm{~h}$. After transcription, DNA templates were removed by DNase treatment and the labeled RNA transcripts were recovered after phenol-chloroform extraction and precipitation with ethanol. The length of the nascent RNA transcripts was verified by electrophoresis. A procollagenase antisense riboprobe was similarly prepared using the EcoRI-linearized pSP64 plasmid containing a cDNA insert for human procollagenase.

\section{Results}

Comparison of metalloproteinase and TIMP $m R N A$ production by human skin fibroblasts and by articular cartilage. The mRNA levels of prostromelysin, procollagenase, and TIMP were analyzed by Northern blotting to compare their relative constitutive levels and the response following IL- $1 \beta$ stimulation. In the case of cartilage explants, prostromelysin was the major metalloproteinase transcript observed and on stimulation with IL-1 $\beta$ the level was further increased (Fig. 1). In contrast, in the case of isolated fibroblasts, procollagenase message was preferentially expressed relative to prostromelysin in unstimulated cells (Fig. 2), albeit at a relatively low level, and this low level was greatly increased after IL-1 $\beta$ stimulation (Fig. 2). In fibroblasts, virtually no prostromelysin message was observed in either stimulated or unstimulated cells (Fig. 2). However, upon longer exposure, the autoradiograph showed a small amount of prostromelysin message in fibroblasts treated with IL-1 $\beta$. TIMP mRNA was expressed in small amounts by both cartilage explants and skin fibroblasts, and IL- $1 \beta$ had little effect on its level in either system (Figs. 1 and 2).

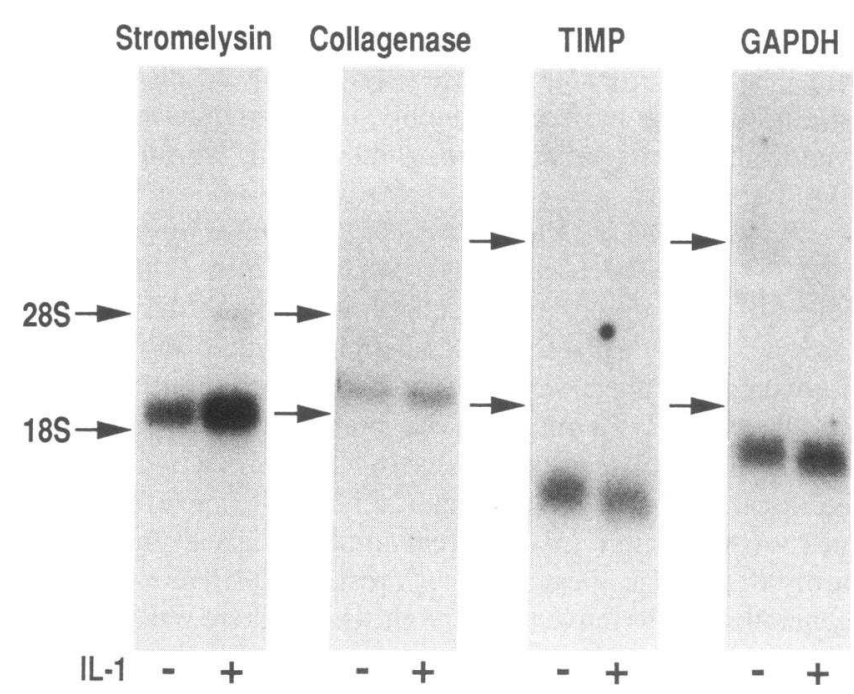

Figure 1. Effect of recombinant IL-1 $\beta$ on the mRNA levels for prostromelysin, procollagenase, and TIMP expressed in adult human articular cartilage explants. Total cellular RNA was prepared from chondrocytes isolated from cartilage explants treated with or without IL- $1 \beta$ for 4 d. $2.5-\mu \mathrm{g}$ samples of RNA were analyzed by Northern blotting using specific cDNA probes. The autoradiograph was exposed either for 3 (prostromelysin and procollagenase) or $9 \mathrm{~h}$ (TIMP and GAPDH). The migration positions of $18 \mathrm{~S}$ rRNA $(1.86 \mathrm{~kb})$ and $28 \mathrm{~S}$ rRNA $(4.71 \mathrm{~kb})$ are also indicated (arrows).

Effect of culture on metalloproteinase mRNA production by isolated chondrocytes. Very little procollagenase mRNA was observed in freshly isolated chondrocytes. However, when such cells were maintained for a short period in culture in the presence of IL-1 $\beta$, stimulation of both prostromelysin and procollagenase mRNA levels was seen (Fig. 3). Under these conditions of high message production, it would appear that high

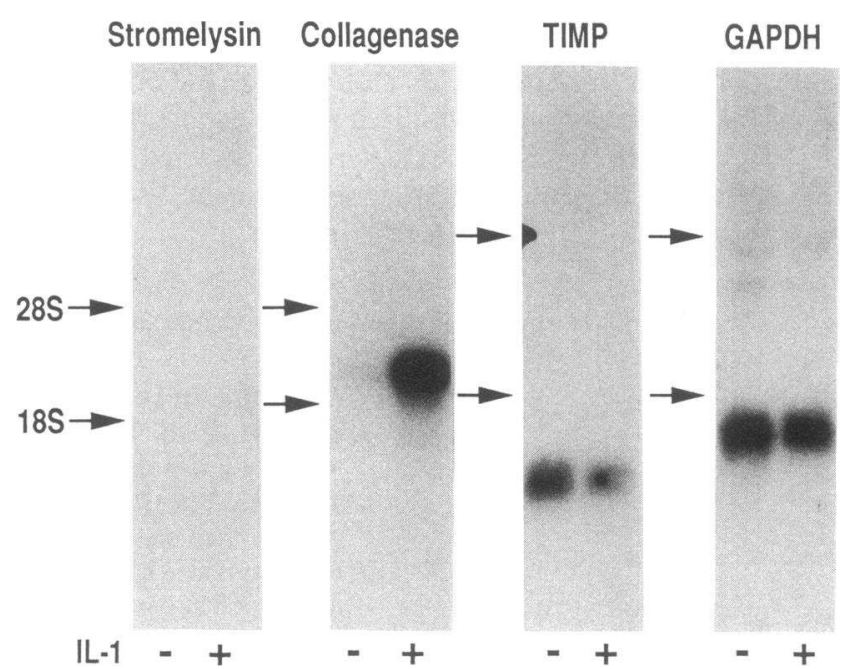

Figure 2. Effect of recombinant IL- $1 \beta$ on the mRNA levels of prostromelysin, procollagenase, and TIMP expressed in normal human skin fibroblasts. Total cellular RNA was prepared from skin fibroblasts cultured with or without IL-1 $\beta$ for $2 \mathrm{~d}$. $2.5-\mu \mathrm{g}$ samples of RNA were analyzed by Northern blotting using specific cDNA probes. The autoradiograph was exposed either for 3 (prostromelysin and procollagenase) or $9 \mathrm{~h}$ (TIMP and GAPDH). The migration positions of $18 \mathrm{~S}$ rRNA (1.86 kb) and 28S rRNA (4.71 kb) are also indicated (arrows). 
molecular weight forms of the prostromelysin mRNA are present. The reason for such a processing anomaly is unclear, but a similar situation has been previously observed in human synovial cells when prostromelysin message is stimulated by IL-1 (27).

Relative steady-state $m R N A$ levels of metalloproteinases and TIMP in normal and osteoarthritic cartilage. The mRNA levels of prostromelysin, procollagenase, and TIMP in chondrocytes freshly isolated from neonatal, normal adult, and osteoarthritic cartilage, were assessed by Northern blotting analysis. Prostromelysin message was preferentially expressed in vivo over procollagenase message in both normal and arthritic adult cartilage (Fig. 4). Abundant amounts of prostromelysin mRNA were found in all normal adult cartilage examined. In arthritic cartilage, the amounts of prostromelysin message were generally less. Relative to the adult tissues, there was minimal prostromelysin mRNA in neonatal cartilage (Fig. 4), with message only being detectable in an overexposed autoradiograph. The apparent low level of prostromelysin mRNA in neonatal cartilage was not due to unequal loading of RNA on the gels, since the level of GAPDH mRNA was comparable to those of other samples. TIMP mRNA was present in all cartilage samples analyzed, with no evidence of TIMP message deficiency in arthritic cartilage.

Localization of metalloproteinase $m R N A$ in normal cartilage. Chondrocytes expressing message for prostromelysin or procollagenase were examined across the total thickness of normal adult human articular cartilage using the technique of in situ hybridization. It was demonstrated that prostromelysin mRNA was localized preferentially in the chondrocytes of the superficial zone (Fig. 5 a). This uppermost layer of adult articular cartilage showed diminished staining for Safranin O. Lack of Safranin O staining was also observed in the pericellular matrix of cells present throughout the cartilage. Under higher magnification, grains due to the prostromelysin antisense riboprobe complexes were visualized directly above the cells, with little evidence for nonspecific localization in the matrix (Fig. 5 $b$ ). The binding between prostromelysin mRNA and the antisense riboprobe was specific, as indicated by the absence of grains in cartilage sections hybridized with the sense riboprobe (Fig. $5 \mathrm{c}$ ). Procollagenase message was also detected solely in chondrocytes of the superficial zone, similar to the distribution pattern of prostromelysin message (Fig. $5 d$ ).

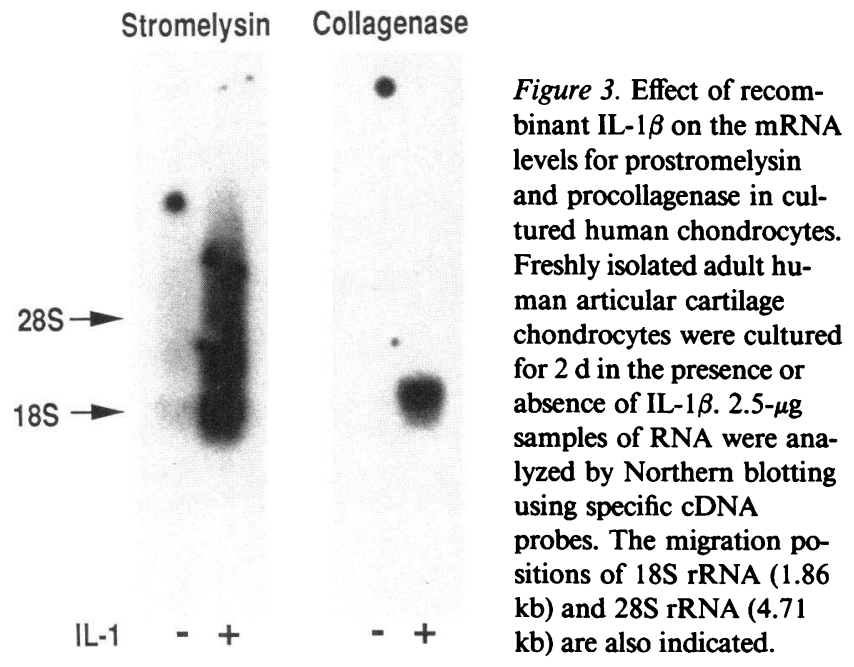

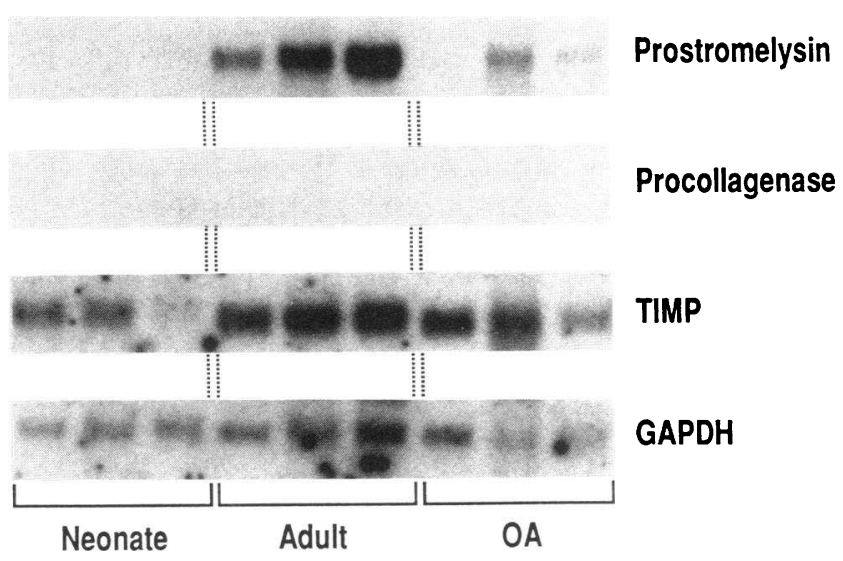

Figure 4. Relative steady-state mRNA levels of prostromelysin, procollagenase, TIMP and GAPDH in neonatal, normal adult, and osteoarthritic cartilage. Total cellular RNA was extracted directly from chondrocytes isolated from neonatal cartilage samples, normal adult cartilage samples, and osteoarthritic $(O A)$ cartilage samples. $2.5-\mu \mathrm{g}$ samples of RNA were analyzed by Northern blotting using cDNA probes specific for prostromelysin, procollagenase, TIMP and GAPDH. The autoradiograph was exposed for 18 (membranes hybridized with prostromelysin or procollagenase probes) or $60 \mathrm{~h}$ (membranes hybridized with TIMP or GAPDH probes).

Localization of metalloproteinase $m R N A$ in cartilage incubated with $I L-1 \beta$. Northern blotting analysis revealed a large increase in the content of prostromelysin mRNA in cartilage explants stimulated with IL- $1 \beta$ (Fig. 1). To investigate further the source of this elevated message level, in situ hybridization was carried out for normal adult cartilage explants treated with or without IL-1 $\beta$ for $4 \mathrm{~d}$ in culture. The matrix of cultured explants completely lacked staining for Safranin O. Virtually no prostromelysin mRNA was detected in tissue sections of the untreated cartilage explant, even in the chondrocytes of the superficial zone (Fig. 6 a). However, prostromelysin message could be localized in all cells throughout the full thickness of the cartilage in sections treated with IL- $1 \beta$ (Fig. $6 b$ ). Thus, all the chondrocytes from the different cartilage zones are capable of prostromelysin mRNA synthesis. Procollagenase mRNA, however, was not detected in tissue sections obtained from either IL-1 $\beta$-stimulated or unstimulated cartilage explants (Fig. $6 c$ ).

Localization of metalloproteinase $M R N A$ in arthritic cartilage. Expression of prostromelysin and procollagenase mRNA in osteoarthritic cartilage obtained from two patients undergoing knee arthroplasty was also examined by in situ hybridization. In comparison with normal adult cartilage, the articular surface of osteoarthritic cartilage was fibrillated, and more matrix area showed an absence of Safranin O staining (Fig. 7). In agreement with Northern blotting analysis (Fig. 4), there was no evidence for an overproduction of metalloproteinase messages in the osteoarthritic cartilage. Both prostromelysin and procollagenase mRNAs were localized only in the chondrocytes of the superficial zone (Fig. 7, $a$ and $c$ ), as observed in normal adult cartilage. On moving towards the erosion site, there was a progressive loss of cells expressing messages for the metalloproteinases (Fig. 7, $a$ and $b$ ). At the erosion site, few cells were observed and often neither prostromelysin nor procollagenase mRNA could be detected. 
a

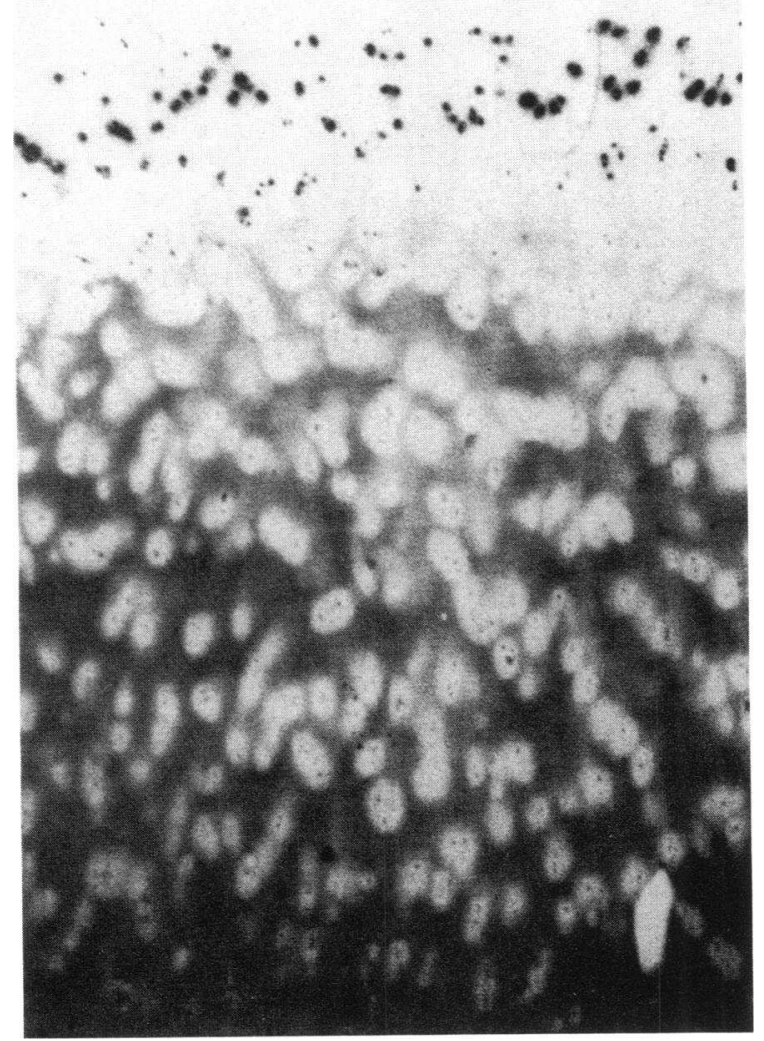

C
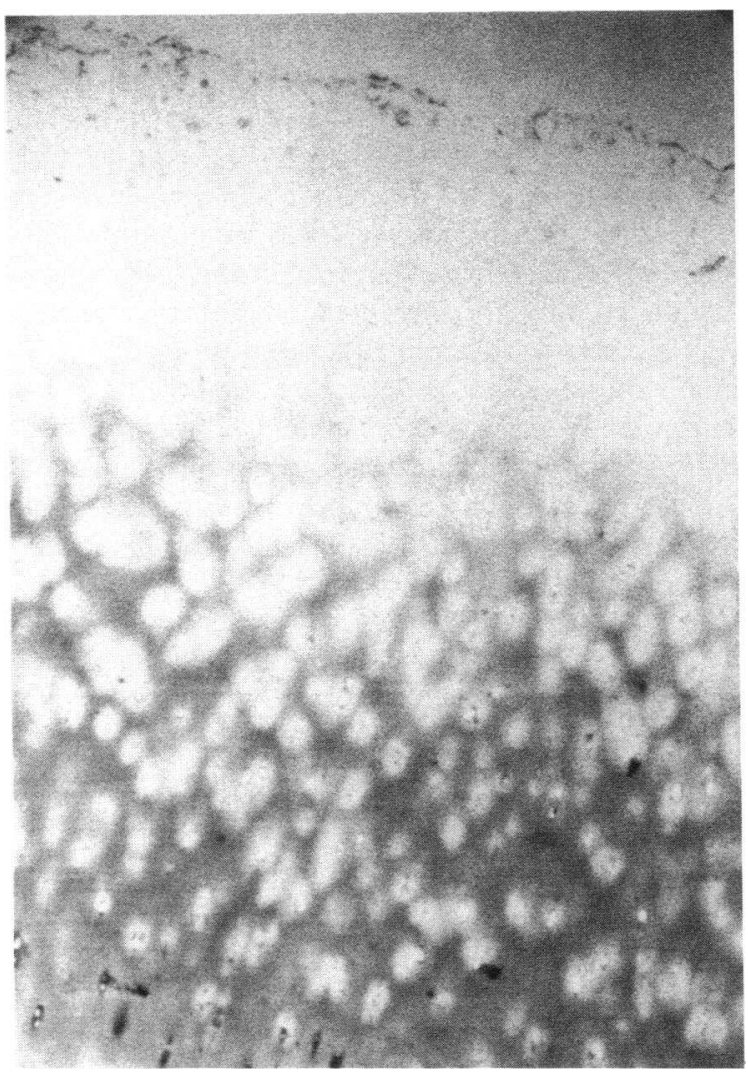

b

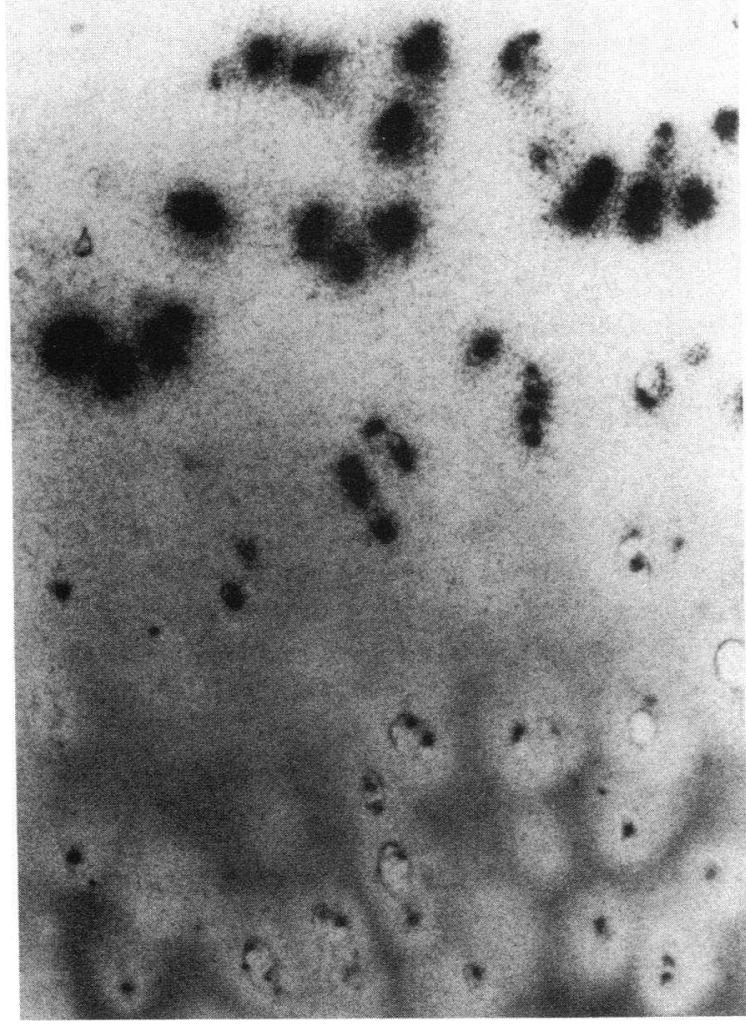

d

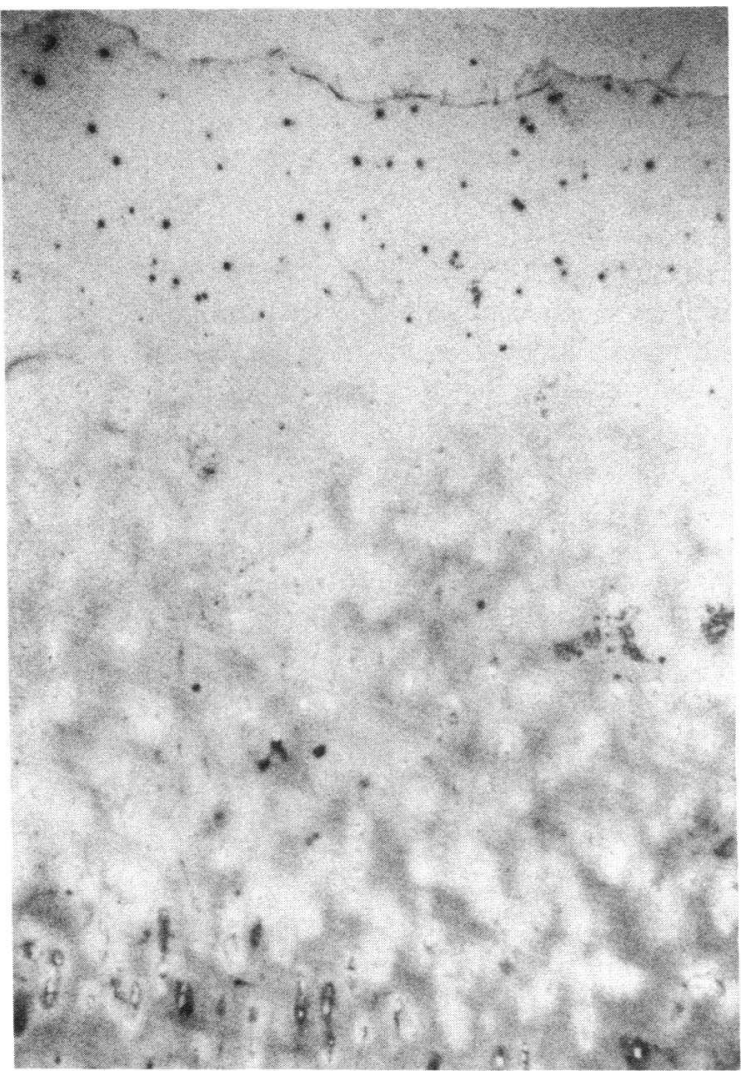

Figure 5. Localization of prostromelysin and procollagenase mRNA in normal adult human articular cartilage. Cryostat sections of femoral condylar cartilage, obtained from a 79-yr-old adult at autopsy, were hybridized with an antisense prostromelysin riboprobe ( $a$ and $b$ ), a sense prostromelysin riboprobe $(c)$, or an antisense procollagenase riboprobe $(d)$. Autoradiography was performed for 2 wk. The sections were counterstained with Safranin O. $a, c$ and $d: \times 90$ : or $b: \times 250$. 


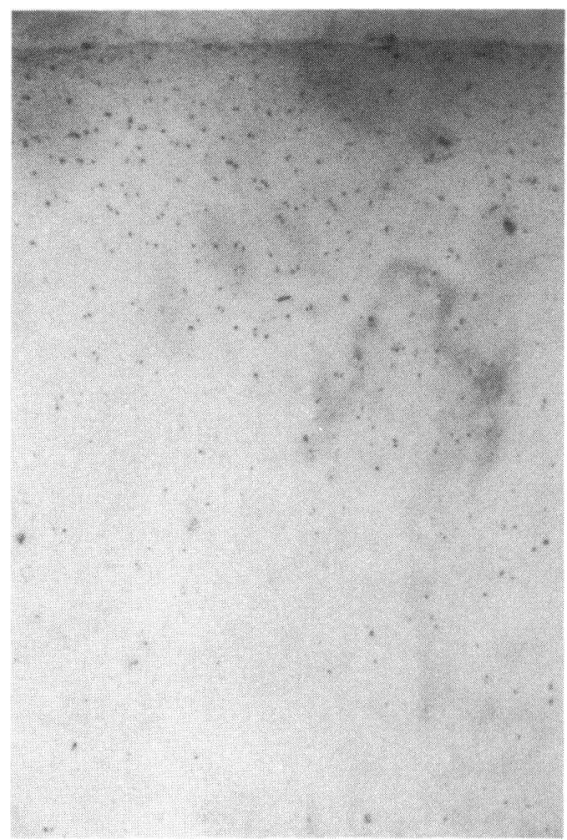

b

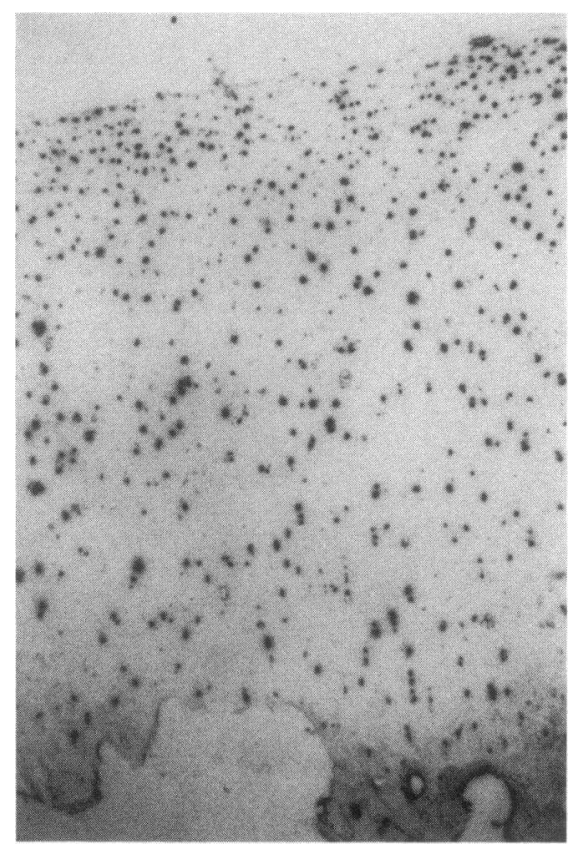

C

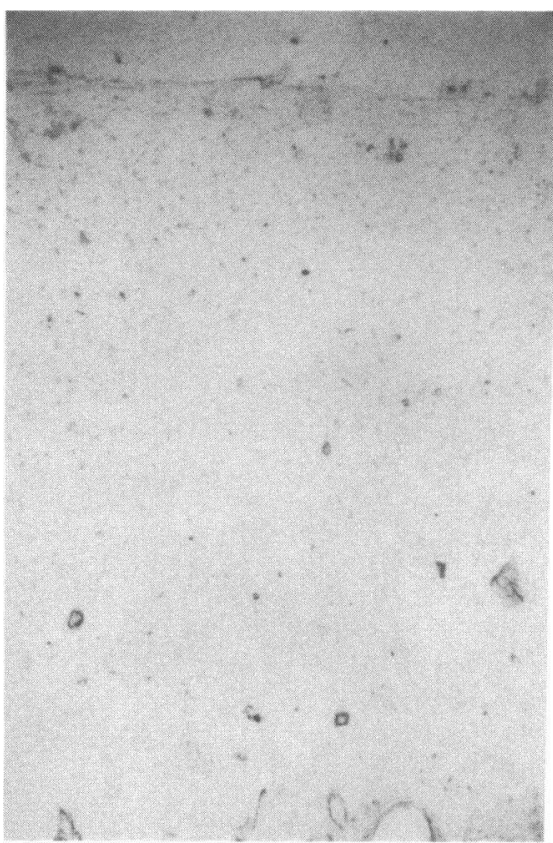

Figure 6. Localization of prostromelysin and procollagenase mRNA in normal adult cartilage explants treated with or without IL-1 $\beta$. Cryostat sections of unstimulated cartilage explants $(a)$ and explants stimulated with IL- $1 \beta$ for $4 \mathrm{~d}(b)$ were hybridized with an antisense prostromelysin riboprobe. Cryostat sections of the stimulated explants were also hybridized with an antisense procollagenase riboprobe (c). Autoradiography was performed for $2 \mathrm{wk}$. The sections were counterstained with Safranin O. $a-c: \times 65$.

\section{Discussion}

In a previous study from this laboratory, it was observed that prostromelysin was by far the major metalloproteinase detectable in the culture medium of human cartilage explants, and that its secretion was greatly stimulated in the presence of IL- $1 \beta$ (19). This was not due to a selective interaction of procollagenase relative to prostromelysin with the cartilage matrix, as little metalloproteinase was found to be retained in the tissue (28). These results are in contrast to the reported stimulation of procollagenase synthesis induced by IL- $1 \beta$ in cell culture of rabbit articular chondrocytes (16) and human chondrocytes (29). However, in agreement with the protein data, this study found very low levels of procollagenase mRNA in unstimulated cartilage explants, and demonstrated that IL- $1 \beta$ had only a limited effect in inducing message production in cartilage organ culture. At the same time, dramatically more prostromelysin mRNA was expressed constitutively, and there was a large increase after IL- $1 \beta$ stimulation. The level of procollagenase mRNA that could be stimulated by IL- $1 \beta$ was, however, increased upon culture of isolated chondrocytes, though prostromelysin message levels were still predominant, unlike the situation present in skin fibroblast cultures. The reason for these differences is not clear. While it is possible that increased levels of IL- $1 \beta$ are required for maximal stimulation of procollagenase relative to prostromelysin in cartilage culture, it is also possible that tissue or environmental differences play a role in the differential regulation of these genes. These findings indicate the danger of extrapolating results from cell culture as representative of the situation in the intact tissue.

Relative to adult cartilage, little prostromelysin message was detected in neonatal cartilage. This was perhaps unex- pected, since evidence for stromelysin activity has been demonstrated in neonatal cartilage (19), and growing tissues may be expected to undergo more proteolytic remodeling than mature tissues. Thus, it appears that the turnover of cartilage matrix components in neonatal cartilage during growth and development is tightly controlled, and that this process may be partly regulated at the level of prostromelysin transcription. In contrast to neonatal cartilage, higher levels of prostromelysin mRNA were consistently observed in adult cartilage, suggesting that in adults control of prostromelysin transcription may not play as important a role in matrix turnover.

In situ hybridization revealed that prostromelysin and procollagenase messages were expressed mainly in chondrocytes of the superficial zone of adult articular cartilage. At the protein level, a similar observation has been made in bovine cartilage. Collagenase activator protein (CAP), which is now recognized to be prostromelysin (30), was shown to be synthesized predominantly in the superficial zone (31). Clearly, chondrocytes at all levels have the potential to synthesize prostromelysin, as illustrated by the uniform pattern of expression seen in cartilage cultured in the presence of IL-1 $\beta$, and therefore the pattern of metalloproteinase mRNA expression reflects a preferential stimulation of the superficial chondrocytes, rather than an inherent deficit in the deeper cells. The reason for such a limited pattern of expression is unclear, although it is possible that there is a higher remodeling activity in the superficial zone in response to the various mechanical forces exerted onto the articular surface. Alternatively, chondrocytes in the superficial zone may be more susceptible to the stimulatory effect of cytokines, which could be present in small amounts in the synovial fluid of normal joints. Irrespective of its mechanism of origin, prostromelysin presumably is released continuously into the su- 

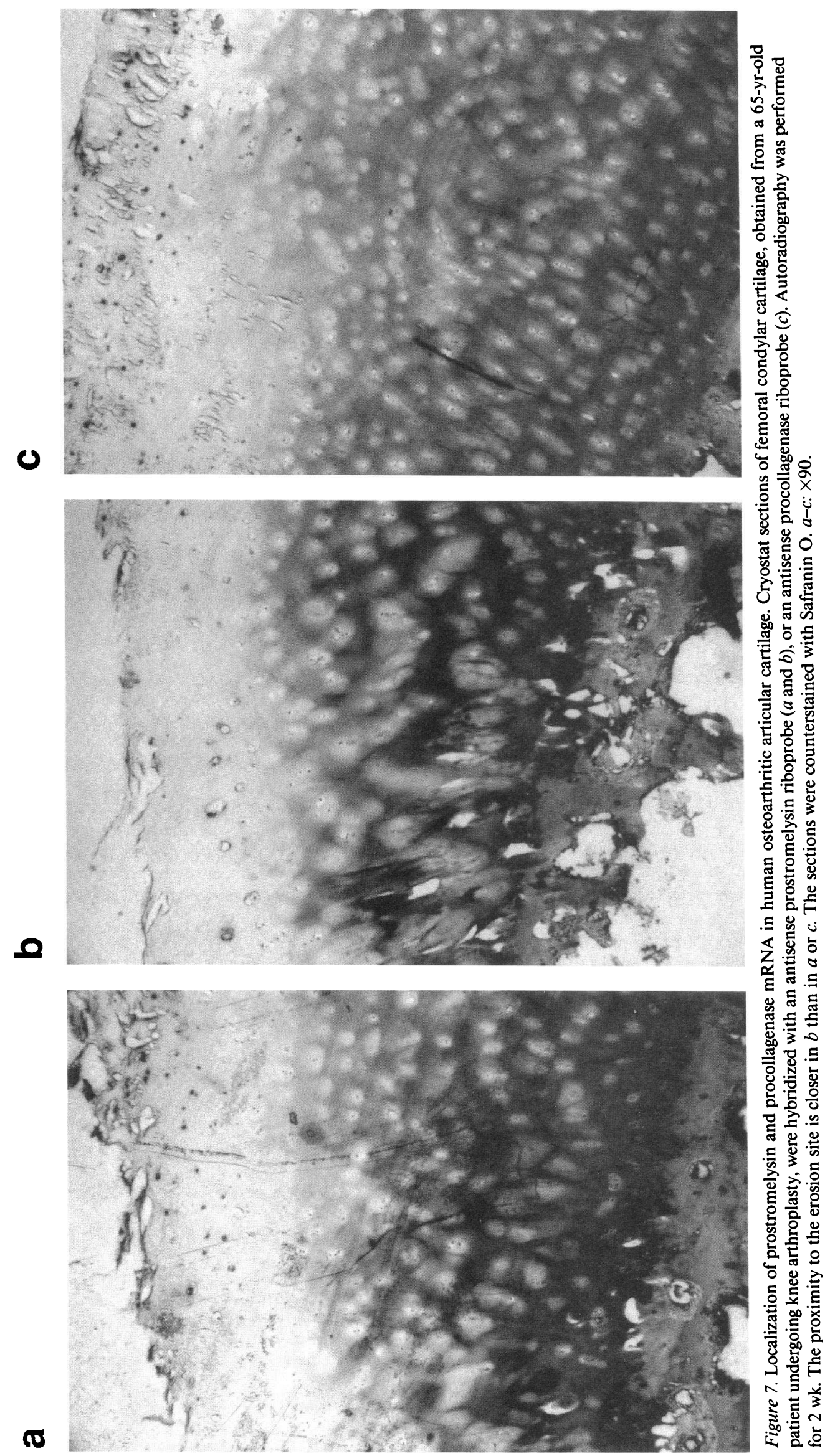
perficial cartilage matrix and could represent a potential hazard. The magnitude of this release may not be uniformly high in all normal individuals, as previous data (21) would suggest considerable heterogeneity in the initial level of proteinase secretion when adult articular cartilage is placed in organ culture. In addition, the presence of high prostromelysin levels may not in itself be of detriment to the cartilage matrix, as the proenzyme is inactive. Substantial evidence exists, however, that in situ activation of the enzyme can occur $(19,21,32)$. If this should occur in an uncontrolled manner, then those individuals with high proenzyme levels in the superficial region of the cartilage would be at risk.

With respect to prostromelysin message, there was generally less TIMP message present in all cartilage specimens examined. Little variation in TIMP message level was observed between specimens, including osteoarthritic cartilage, even though diminished TIMP activity has been reported for human osteoarthritic cartilage (33). However, quantitation of TIMP by measurement of proteinase inhibition cannot detect enzyme/inhibitor complexes, and such complexes have been shown to be present in human articular cartilage (34). In adult cartilage, it is apparent that total metalloproteinase message often exceeds that of TIMP message. If this translates into more latent metalloproteinase than TIMP, then the degradative potential of the cartilage exceeds its inhibitory capacity.

Fibrillation of the articular surface, and diminished superficial Safranin O staining, are indicative of proteolytic changes in the osteoarthritic cartilage, so the lack of evidence for increased mRNA levels of metalloproteinases in the osteoarthritic cartilage was surprising, as mRNA levels commonly reflect secreted protein levels. A number of factors could, however, contribute to this observation. As with normal adult cartilage, both prostromelysin and procollagenase mRNAs were only detected in chondrocytes of the superficial zone, with no evidence for a global activation of chondrocytes throughout the cartilage matrix. Near the osteoarthritic erosion site, the superficial zone was completely absent, and depletion in this superficial chondrocyte population would be expected to diminish the average relative steady state mRNA levels of the metalloproteinases. A second contributory factor could be the pharmacological status of the cartilage, as all patients were undergoing drug therapy before surgery. The possibility therefore exists that the low level of prostromelysin mRNA expression could be due to the inhibition of synthesis by anti-inflammatory drug therapy (35). Finally, one should also consider the possibility of differences being caused artifactually due to the time incurred after death for collection of control autopsy specimens compared to fresh surgical material. The main difference between these two situations would be the absence of blood circulation in the former case for up to $20 \mathrm{~h}$ before tissue collection. However, it is unlikely that changes in oxygen tension in the surrounding tissue would greatly effect the chondrocytes, since it has been shown that these cells undergo anaerobic metabolism, even under normal circumstances $(36,37)$. Furthermore, if local hormonal or nutrient changes caused by the lack of blood circulation could result in stimulation of chondrocyte biosynthesis by an autocrine mechanism, one would expect similar effects in both the adult and neonatal autopsy specimens, which was not the case.

Other workers have reported higher total endogenous proteoglycan and collagen-degrading activities in osteoarthritic cartilage relative to normal tissue, and an increase in the level of metalloproteinase activity toward the erosion center (11, 12). It is possible that the tissue remaining on the late stage osteoarthritic joints used in this study may have been undergoing more of a reparative phase of the disorder than a degenerative phase (38), and therefore have properties resembling neonatal cartilage. Indeed, this might be the reason that it had survived. The intense Safranin O staining in the deep zones of the osteoarthritic cartilage would support such a concept. Interestingly, some growth factors, such as transforming growth factor- $\beta$, which promote tissue repair by stimulating matrix synthesis, also down-regulate metalloproteinase synthesis (39). If this is the case, then the observation reported for the osteoarthritic cartilage used in this study may in no way reflect the situation in an actively degenerating joint, with respect to the level of prostromelysin mRNA.

In conclusion, our data suggest that if the metalloproteinases do play a role in the turnover of adult cartilage, then the level of activation rather than the rate of synthesis of the latent precursor may be the prime factor determining the detrimental depletion of cartilage extracellular matrix components. Furthermore, such activation is presumably deficient in normal adult articular cartilage, as this tissue appears to be constitutively primed with abundant amounts of the message for the latent precursor, and is therefore likely to be producing abundant prostromelysin.

\section{Acknowledgments}

We thank Drs. D. Zukor (Royal Victoria Hospital, Montreal, Quebec) and C. E. Brookes (Montreal General Hospital, Montreal, Quebec) for providing arthritic surgical samples; Dr. N. Beauchemin (McGill Cancer Center, Montreal, Quebec) for her assistance with in situ hybridization; Mr. B. E. Hakala for his help in establishing the PCR conditions; Mr. E. Wan for the synthesis of oligonucleotide primers; and Ms. J. Wishart for preparing the figures. We also thank the Departments of Pathology at the Royal Victoria Hospital, the Montreal General Hospital, and Hôpital Sainte Justine for the provision of autopsy facilities.

This work was supported by the Arthritis Society of Canada, the Shriners of North America and a Canadian Medical Research Council studentship to Q. Nguyen.

\section{References}

1. Khokha, R., and D. T. Denhardt. 1989. Matrix metalloproteinases and tissue inhibitor of metalloproteinases: $A$ review of their role in tumorigenesis and tissue invasion. Invasion Metastasis. 9:391-405.

2. Murphy, G., H. Nagase, and C. E. Brinckerhoff. 1988. Relationship of procollagenase activator; stromelysin and matrix metalloproteinase 3. Collagen Relat. Res. 8:389-391.

3. Matrisian, L. M. 1990. Metalloproteinases and their inhibitors in matrix remodeling. Trends in Genet. 6:121-125.

4. Van Wart, H. E., and H. Birkedal-Hansen. 1990. The cysteine switch: a principle of regulation of metalloproteinase activity with potential applicability to the entire matrix metalloproteinase gene family. Proc. Nat. Acad. Sci. USA. 87:5578-5582.

5. Schmid, T. M., R. Mayne, J. J. Jeffrey, and T. F. Linsenmayer. 1986. Type $\mathrm{X}$ collagen contains two cleavage sites for a vertebrate collagenase. J. Biol. Chem. 261:4184-4189.

6. Chin, J. R., G. Murphy, and Z. Werb. 1985. Stromelysin, a connective tissue-degrading metalloendopeptidase secreted by stimulated rabbit synovial fibroblasts in parallel with collagenase. Biosynthesis, isolation, characterization, and substrates. J. Biol. Chem. 260:12367-12376.

7. Okada, Y., H. Konomi, T. Yada, K. Kimata, and H. Nagase. 1989. Degradation of type IX collagen by matrix metalloproteinase 3 (stromelysin) from human rheumatoid synovial cells. FEBS (Fed. Eur. Biochem. Soc.) Lett. 244:473-476.

8. Murphy, G., M. I. Cockett, P. E. Stephens, B. J. Smith, and A. J. P. Docherty. 1987. Stromelysin is an activator of procollagenase. A study with natural and recombinant enzymes. Biochem. J. 248:265-268. 
9. Cawston, T. E., W. A. Galloway, E. Mercer, G. Murphy, and J. J. Reynolds. 1981. Purification of rabbit bone inhibitor of collagenase. Biochem. J. 195:159165.

10. Murphy, G., M. B. McGuire, R. G. G. Russell, and J. J. Reynolds. 1981. Characterization of collagenase, other metallo-proteinases and an inhibitor (TIMP) produced by human synovium and cartilage in culture. Clin. Sci. 61:711716.

11. Pelletier, J.-P., J. Martel-Pelletier, D. S. Howell, L. Ghandur-Mnaymneh, J. E. Enis, and J. F. Woessner. 1983. Collagenase and collagenolytic activity in human osteoarthritic cartilage. Arthritis Rheum. 26:63-68.

12. Martel-Pelletier, J., J.-P. Pelletier, J.-M. Cloutier, D. S. Howell, L. Ghandur-Mnaymneh, and J. F. Woessner. 1984. Neutral proteases capable of proteoglycan digesting activity in osteoarthritis and normal human articular cartilage. Arthritis Rheum. 27:305-312.

13. Woolley, D. E., M. J. Crossley, and J. M. Evanson. 1977. Collagenase at the sites of cartilage erosion in the rheumatoid joint. Arthritis Rheum. 20:12311239.

14. Okada, Y., N. Takeuchi, K. Tomita, I. Nakanishi, and H. Nagase. 1989. Immunolocalisation of matrix metalloproteinase 3 (stromelysin) in rheumatoid synovioblasts (B cells): Correlation with rheumatoid arthritis. Ann. Rheum. Dis. 48:645-653.

15. Dinarello, C. A. 1989. Interleukin-1 and other growth factors. In Textbook of Rheumatology. 3rd ed. Kelley, W. N., E. D. Harris, S. Ruddy, and C. B. Sledge, editors. W. B. Saunders, Philadelphia, PA. 285-299.

16. Murphy, G., R. M. Hembry, and J. J. Reynolds. 1986. Characterization of a specific antiserum to rabbit stromelysin and demonstration of the synthesis of collagenase and stromelysin by stimulated rabbit articular chondrocytes. Collagen Relat. Res. 6:351-364.

17. Tyler, J. A. 1985. Articular cartilage cultured with catabolin (pig interleukin 1) synthesizes a decreased number of normal proteoglycan molecules. Biochem. J. 227:869-878.

18. Goldring, M. B., J. Birkhead, L. J. Sandell, T. Kimura, and S. M. Krane 1988. Interleukin 1 supresses expression of cartilage-specific types II and IX collagens and increases types I and III collagens in human chondrocytes. J. Clin Invest. 82:2026-2037.

19. Nguyen, Q., G. Murphy, P. J. Roughley, and J. S. Mort. 1989. Proteoglycan aggregate degradation by a cartilage metalloproteinase. Evidence for the involvement of stromelysin in the generation of link protein heterogeneity in situ. Biochem. J. 259:61-67.

20. Handley, C. J., and D. A. Lowther. 1977. Extracellular matrix metabolism by chondrocytes. III. Modulation of proteoglycan synthesis by extracellular levels of proteoglycan in culture. Biochim. Biophys. Acta. 500:132-139.

21. Campbell, I. K., A. Guttman, E. E. Golds, P. J. Roughley, and J. S. Mort. 1989. Variation in the effects of mononuclear cell products from different individuals on metalloproteinase secretion from human articular cartilage. J. Rheumatol. $16: 1552-1558$.

22. Chomczynski, P., and N. Sacchi. 1987. Single-step method of RNA isolation by acid guanidinium thiocyanate-phenol-chloroform extraction. Anal. Biochem. 162:156-159.

23. Whitham, S. E., G. Murphy, P. Angel, H.-J. Rahmsdorf, B. J. Smith, A. Lyons, T. J. R. Harris, J. J. Reynolds, P. Herrlich, and A. J. P. Docherty. 1986. Comparison of human stromelysin and collagenase by cloning and sequence analysis. Biochem. J. 240:913-916.
24. Tso, T.-Y., X.-H. Sun, T.-H. Kao, K. S. Reece, and R. Wu. 1985. Isolation and characterization of rat and human glyceraldehyde-3-phosphate dehydrogenase cDNAs: genomic complexity and molecular evolution of the gene. Nucleic Acids Res. 13:2485-2502.

25. Sirum, K. L., and C. E. Brinckerhoff. 1989. Cloning of the genes for human stromelysin and stromelysin 2: Differential expression in rheumatoid synovial fibroblasts. Biochemistry. 28:8691-8698.

26. Carmichael, D. F., A. Sommer, R. C. Thompson, D. C. Anderson, C. G. Smith, H. G. Welgus, and G. P. Stricklin. 1986. Primary structure and cDNA cloning of human fibroblast collagenase inhibitor. Proc. Nat. Acad. Sci. USA. 83:2407-2411.

27. Saus, J., S. Quinones, Y. Otani, H. Nagase, E. D. Harris, and M. Kurkinen. 1988. The complete primary structure of human matrix metalloproteinase-3. Identity with stromelysin. J. Biol. Chem. 263:6742-6745.

28. Liu, J., P. J. Roughley, and J. S. Mort. 1991. Identification of human intervertebral disc stromelysin and its involvement in matrix degradation. $J$. Orthop. Res. 9:568-575.

29. Stephenson, M. L., M. B. Goldring, J. R. Birkhead, S. M. Krane, H. J. Rahmsdorf, and P. Angel. 1987. Stimulation of procollagenase synthesis parallels increases in cellular procollagenase mRNA in human articular chondrocytes ex posed to recombinant interleukin 1-beta or phorbol ester. Biochem. Biophys. Res. Commun. 144:583-590.

30. Gunja-Smith, Z., H. Nagase, and J. F. J. Woessner. 1989. Purification of the neutral proteoglycan-degrading metalloproteinase from human articular cartilage tissue and its identification as stromelysin matrix metalloproteinase-3. BiOchem. J. 258:115-119.

31. Treadwell, B. V., J. Neidel, M. Pavia, C. A. Towle, M. E. Trice, and H. J. Mankin. 1986. Purification and characterization of collagenase activator protein synthesized by articular cartilage. Arch. Biochem. Biophys. 251:715-723.

32. Campbell, I. K., P. J. Roughley, and J. S. Mort. 1986. The action of human articular cartilage metalloproteinase on proteoglycan and link protein Similarities between in situ and in vitro degradation products. Biochem. J. 237:117-122.

33. Azzo, W., and J. F. Woessner. 1986. Purification and characterization of an acid metalloproteinase from human articular cartilage. J. Biol. Chem. 261:5434-5441.

34. Dean, D. D., J. Martel-Pelletier, J. P. Pelletier, D. S. Howell, and J. F. J. Woessner. 1989. Evidence for metalloproteinase and metalloproteinase inhibitor imbalance in human osteoarthritic cartilage. J. Clin. Invest. 84:678-685.

35. Pelletier, J.-P., J.-M. Cloutier, and J. Martell-Pelletier. 1989. In vitro effects of tiaprofenic acid, sodium salicylate and hydrocortisone on the proteoglycan metabolism of human ostoarthritic cartilage. J. Rheumatol. 16:646-655.

36. Nahir, A. M. 1987. Aerobic glycolysis: a study of human articular cartilage. Cell Biochem. Funct. 5:109-112.

37. Spencer, C. A., T. N. Palmer, and R. M. Mason. 1990. Intermediary metabolism in the Swarm rat chondrosarcoma chondrocyte. Biochem. J. 265:911-914.

38. Mankin, H. J., K. D. Brandt, and L. E. Shulman. 1986. Workshop on etiopathogenesis of osteoarthritis. Proceedings and recommendations. J. Rheumatol. 13:1130-1160.

39. Rizzino, A. 1988. Transforming growth factor-beta: multiple effects on cell differentiation and extracellular matrices. Dev. Biol. 130:411-422. 